рассматривается на примере специалистов IT-компаний (n = 182) из четырех стран Центральной и Восточной Европы. Доказано, что основными диспозициональными чертами, которые содействуют реализации деятельностного потенциала, выступают добросовестность и открытость опыту. Тогда как среди ценностных ориентаций такими предикторами выступают ориентации на компетентное и толерантное лидерство. Важными также в этом аспекте выступают ценностные ориентации на альтруизм и независимость. В свою очередь, ориентация на социальную поддержку затрудняет реализацию в деятельности ориентации на качество и усиливает ощущение неуверенности в собственных силах. Выявлено, что в условиях реструктуризации основную роль начинают играть диспозициональные факторы, а степень ценностной регуляции снижается.

Ключевые слова: IT-специалисты, психологические предикторы, дистанционная работа, управленческой потенциал, личностные черты, ценностные ориентации.

N. Maksymenko, post-graduate,

Ilya Mechnikov National University of Odessa, Odessa, Ukraine

\title{
THE PSYCHOLOGICAL PREDICTORS OF ACTIVITY OF IT-PROFESSIONAL SINCONDITIONS OF ORGANIZATIONAL TRANSITION TO REMOTE WORK
}

The article is devoted to the actual problem of psychological support of the transition of office workers to remote work. The purpose of the article is the definition of psychological and socio-demographic determinants of the activities of managers in the context of junior personnel transfer to virtual / home office. This problem is considered on the example of IT-professionals $(n=182)$ from four countries of Central and Eastern Europe. It is proved that the basic dispositional features that contribute to the realization of the activity potential are conscientiousness and openness to experience. Among the value orientations such predictors are the orientations towards competent and tolerant leadership. Another important thing is the value orientations of altruism and independence. The author makes conclusion that duing formation of uncertainty in their actions, individual personal traits play a great role, especially such traits as: ease of occurrence of negative emotions, individualism, preference for independence, disorganization, spontaneity, low level of purposeful behavior. Therefore, an orientation towards social support makes it difficult to implement an orientation towards quality in an activity and reinforces the lack of self-confidence feelings. It was revealed that under conditions of restructuration dispositional factors begin to play a major role, and the degree of value regulation decreases. In addition, the author suggests that a low level of integrity promotes creativity. This can be explained by the fact that an individual, who has such low level, remains open for longer to various possibilities of thought and action. The results of the analysis of the research data indicate that value orientations act as a kind of basis. They head the realization of the personal characteristics of a specialist in professional activity and they are important qualities in everyday life. In the article it is determined that the desire for success decreases in the specialists who get older, and the value orientations for support and leadership contribute to this aspiration. The author has shown that openness of experience, combined with tolerant leadership, is a prerequisite for determination in promoting organizational change.

Keywords: IT professionals, psychological predictors, remote work, managerial potential, personality traits, value orientations.

Bulletin of Taras Shevchenko National University of Kyiv.

Series "Psychology". № 2(9), pp. 42-47 (2018)

УДК 159.9

DOI: https://doi.org/10.17721/BSP.2018.2(9).11
ISSN 1728-3817

(c) Taras Shevchenko National University of Kyiv,

Publishing Center "Kyiv University", 2018

В. Мозговий, канд. психол. наук, докторант Київський національний університет імені Тараса Шевченка, Київ

\section{ДОСЛІДЖЕННЯ СТРУКТУРНОї ОРГАНІЗАЦІЇ ОСОБИСТОСТІ ВІЙСЬКОВОСЛУЖБОВЦІВ, ЯКІ СХИЛЬНІ ДО ЗЛОВЖИВАННЯ АЛКОГОЛЮ, У КОНТЕКСТІ ЇХ СТАТЕВОРОЛЬОВОГО СТАТУСУ}

Досліджено особливості структурної організацї особистості військовослужбовців, що схильні до зловживання алкоголю. Визначено подальший фокус роботи психолога військової частини з даною категорією осіб залежності від виявленого статеворольового статусу військовослужбовців, що схильні до зловживання алкоголю.

Ключові слова: факторна структура особистості, статеворольовий статус, військовослужбовець.

Постановка проблеми. За розпивання алкогольних і слабоалкогольних напоїв командирами військових частин, які виконували завдання за призначенням у зоні проведення антитерористичної операції із 2014 по 2017 р., до суду було направлено 17040 адміністративних протоколів. Військовою прокуратурою відкрито 400 кримінальних проваджень за фрактами вчинення військовослужбовцями злочинів у стані алкогольного сп'яніння. Наведені сумні фракти вживання алкоголю в армії призводять до небойових і часто безповоротних утрат, що безумовно впливає на боєздатність військових підрозділів [1]

Так, у довгостроковій перспективі вживання алкоголю призводить до структурних змін в особистості військовослужбовця, що згодом може поставити під питання його професійну відповідність до вимог військової служби та призвести до загального зниження боєздатності військових підрозділів.

Отже актуальним постає питання виявлення структурної організації особистості військовослужбовця зі схильністю до адиктивної поведінки, а саме до зловживання алкоголю $з$ метою визначення фокусу роботи психолога частини з даною категорією осіб на всіх етапах психологічного супроводу.

Також у контексті нашого дослідження актуальним $\epsilon$ виявлення вираженості статеворольових характеристик у структурній організації особистості, адже вони можуть виступати стрижневими характеристиками, які провокують формування відповідних особистісних якостей та мотивів. До того ж статеворольові характеристики у структурній організації особистості військовослужбовців, схильних до адиктивної поведінки, не були предметом ретельного наукового дослідження.

Аналіз останніх досліджень і публікацій. Дослідженням цих питань, а саме виявів адиктивної поведінки у військовослужбовців та її впливу на виконання завдань за призначенням, займались такі дослідники: С. П. Балашова, І. С. Бахтін, С. П. Васильєв, Г. Р. Дубровинський, А. Д. Савін, О. М. Сукачова тощо.

С. П. Балашова, С. П. Васильєв, Г. Р. Дубровинський чітко визначили зміст трьох груп фракторів: соціальних, психологічних та біологічних, які сприяють пияцтву у військовослужбовців, та напрями профрілактики пияцтва серед військовослужбовців. Так, до соціальних факторів належать: 1) несприятливі умови сімейного виховання, неповна сім'я, алкогольні традиції сім'ї, низький культурний рівень, конфліктні взаємовідносини і аморальна поведінка батьків; 2) низький рівень освіти, низька успішність у школі; 3) ранній вступ у самостійне життя, початок трудової діяльності до 17 років; 4) раннє вживання алкоголю; 5) плив неформальної групи однолітків із асоціальними тенденціями; 6) культурні традиції. До психологічних фракторів належать: 1) певні 
особливості особистості, завдяки яким релаксуючі та ейфоризуючі властивості алкоголю сприяють розвитку почуття "психічного комфорту" і полегшують міжособистісні контакти; 2) фіксація цих станів. До біологічних факторів належать: 1) черепно-мозкові травми та інтоксикації; 2) несприятлива спадковість (народження у сім'ї алкоголіків) [2, с. 160]. Науковці вказують, що майбутні алкоголіки виховуються у конфліктних сім'ях із порушенням емоційних зв'язків між її членами, що сприяє десоціалізації дитини, фрормує неадекватне розуміння причинно-наслідкових зв'язків у розвитку емоційних станів. Спостерігається значна невротична залежність від матері та низька оцінка ролі батька у сімейному житті, у подружньому житті - жіноче домінування. У 25$32 \%$ випадків у них спостерігається нестійкий, епілептоїдний, експлозивний або гіпертимний типи акцентуацій характеру [2, с. 159].

А. Д. Савін у своїй роботі розглядав поняття відхильної поведінки у військовослужбовців, зокрема й адиктивної. У своєму дослідженні він дійшов висновку, що розглядати сутність адиктивної поведінки у військовослужбовців необхідно в контексті вивчення соціальнопсихологічних особливостей їх особистості. "Особистість $€$ цілісною системою з нерозривною єдністю взаємопов'язаних якостей, які індивід набуває в конкретноісторичних умовах існування в процесі діяльності, спілкування та пізнання" [3, с. 125].

О. М. Сукачова, досліджуючи структуру мотивів споживання алкоголю на рівні мотиваційної напруженості споживання у колишніх кадрових військовослужбовців, дійшла висновку, що вони можуть бути непатологічними (наслідування традицій), зазнавати трансформації та змінюватися на атарактичні, а також бути патологічними, такими, як самоушкодження [4, с. 107].

І. С. Бахтін у своєму дослідженні факторної структури особистості курсантів вищих військових навчальних закладів, схильних до адиктивної поведінки та вживання алкоголю, установив, що сукупність таких особистісних властивостей, як низька товариськість, прагнення до домінування і низька емоційна чутливість, можуть призводити до такої поведінки [5, с. 156].

Цікаві результати досліджень осіб, схильних до алкозалежності, наводить у своїх роботах Л. Уманець. Так, на основі любові з боку батьків у дитини формується здатність любити себе та її самооцінка, - усе це утворює основу духовного здоров'я та дає змогу досягти зрілості. Відхилення від нормального шляху цього розвитку стає причиною багатьох неврозів. На фоні перебільшеної залежності від батька розвивається невроз нав'язливих станів, а у разі надмірної концентрації прихильності до матері - істерія, алкоголізм, депресія, нездатність до самоствердження [6]. Разом із тим, за визначенням Е. А. Сергієнка, "депривація" $є$ відхиленням від середовищного континууму, який $є$ революційно очікуваним, характерним для певного віку [7]. Деприва- ція зумовлює відставання у психічному розвиткові за багатьма параметрами. Вона негативно позначається на самосвідомості, служить причиною розладів і дисгармоній у процесі становлення образу "Я", шкодить психічному розвиткові особистості, як зазначають 3. Матейчек та Й. Лангмейєр [8].

Метою нашої роботи було дослідити фракторну структуру особистісної організації військовослужбовців, схильних до зловживання алкоголю для визначення фокусу роботи психолога під час їх психологічного супроводу на всіх етапах військової служби. Виходячи 3 мети дослідження, нами були сформовані такі дослідницькі завдання:

1. Дослідити специфіку факторної структури військовослужбовців, схильних до алкоголізації, та визначити основні стрижневі ознаки їх психологічного портрету.

2. Виявити показники які, із застосованих у дослідженні методик, є чутливими до визначення критеріальних вимог виявлення військовослужбовців, схильних до алкозалежності.

3. Визначити фокус впливу психолога військової частини на особистість військовослужбовців, схильних до виявів адиктивних фрорм поведінки, та окреслити основні шляхи психокорекційної роботи з особовим складом, схильного до зловживання алкоголю залежно від статево-рольового статусу.

Основу дослідницької вибірки становили 64 військовослужбовця Державної спеціальної служби транспорту (ДССТ) МО України, які були виявлені за скрінінг-тестом "СAGE" психологом військової частини та офріцерами морально-психологічного забезпечення під час вивчення особового складу.

Для дослідження особливостей структурної організації особистості військовослужбовців, схильних до зловживання алкоголю, нами було використано методики, які зазначені у методичних рекомендаціях Адміністрації ДССТ: "Прогноз", СЗЧ-4, HADS, CP-10, а також особистісний опитувальник Кеттела, тест Шмішека і анкета самооцінки.

Для вивчення гендерних та психологічних особливостей особистості військовослужбовців, які схильні до вияву аддиктивних форм поведінки, нами були використані методика С. Бем (визначення рівневої оцінки маскулінності/фремінінності) та структурна статево-рольова шкала (А. С. Кочаряна -Є. В. Фролової, а також показники Dur-Moll (маскулінність-фемінінність відповідно) за методикою С. Сонді.

Отримані дані було піддано процедурі математикостатистичного аналізу за допомогою програми SPSS Statistic.

Виклад основного матеріалу. У табл. 1 подано особистісну факторну структуру військовослужбовців, схильних до зловживання алкоголю, яка містить три фактори, що пояснюють 63,800 \% внеску сукупної дисперсії.

Факторна структура особистості в/с, які схильні до зловживання алкоголю

Таблиця 1

\begin{tabular}{|c|c|c|}
\hline № & Назва & Внесок до сукупної дисперсії (у \%) \\
\hline 1 & комплексної дезадаптації & 28,955 \\
\hline 2 & тривожності та фемінності & 18,226 \\
\hline 3 & гендерної невизначеності & 16,619 \\
\hline
\end{tabular}

Загальний аналіз фракторної структури військовослужбовців, схильних до вживання алкоголю, виявив стрижневі показники, характерні для даної категорії осіб. Це шкали нервово-психічної нестійкості й ризику до нервового зриву, що є шкалами методики "Прогноз" та особиста готовність до використання зброї, яка має інверсивну динаміку і $є$ показником анкети суб'єктивної самооцінки.
Аналіз кожного із виявлених фракторів характеризується певною специфікою. У результаті пакет відібраних психодіагностичних методик дозволив нам охарактеризувати дану групу військовослужбовців з боку вимог професійної придатності, особливостей характеру, особистісних особливостей, а також вираженості статеворольових характеристик і суб'єктивної самооцінки. 
У табл. 2 подано психологічні характеристики першого фактора особистісної структури військовослужбовців, схильних до зловживання алкоголю. Так, до першого фрактора увійшли такі показники, як суїцидальна схильність $(0,861)$; тривожність (HADS 0,806); нервово-психічна нестійкість $(0,784)$; рівень суїцидального ризику $(0,775)$; схильність до ухилення від військової служби $(0,746)$ і ризик нервового зриву $(0,617)$ за методиками, визначеними штабом Адміністрації. Подані характеристики у своїй сукупності вказують на відсутність достатнього рівня особистої психологічної стійкості у цих військовослужбовців до стресового впливу військової служби.

Таблиця 2

\begin{tabular}{|c|c|c|c|c|c|}
\hline 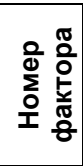 & $\begin{array}{c}\text { Показники } \\
\text { відповідності } \\
\text { до вимог ВС } \\
\text { (Прогноз; С3Ч-4; } \\
\text { HADS; CP-10) }\end{array}$ & $\begin{array}{c}\text { Шмішек } \\
\text { (Характер) }\end{array}$ & $\begin{array}{c}\text { Кеттел } \\
\text { (Особистість) }\end{array}$ & $\begin{array}{c}\text { Статеворольові } \\
\text { характеристики } \\
\text { (К-Ф; СБ; D-М)* }\end{array}$ & $\begin{array}{l}\text { Суб'єктивна } \\
\text { самооцінка }\end{array}$ \\
\hline 1 & $\begin{array}{l}\text { Суїцидальна схи- } \\
\text { льність }(0,861) \text {. } \\
\text { Тривожність } \\
\text { (HADS) }(0,806) \text {. } \\
\text { Нервово-психічна } \\
\text { нестійкість }(0,784) \text {. } \\
\text { Рівень суїцидаль- } \\
\text { ного ризику } \\
(0,775) . \\
\text { Схильність до } \\
\text { ухилення від вій- } \\
\text { ськової служби } \\
\text { (0,746). Ризик } \\
\text { нервового зриву } \\
(0,617) .\end{array}$ & $\begin{array}{l}\text { Vo збудливість } \\
(0,697) \text {. } \\
\text { Tr тривожність } \\
(0,551) \text {. } \\
\text { Сіциклотимність } \\
(0,544) \text {. } \\
\text { Ре-педантизм } \\
(0,544) .\end{array}$ & 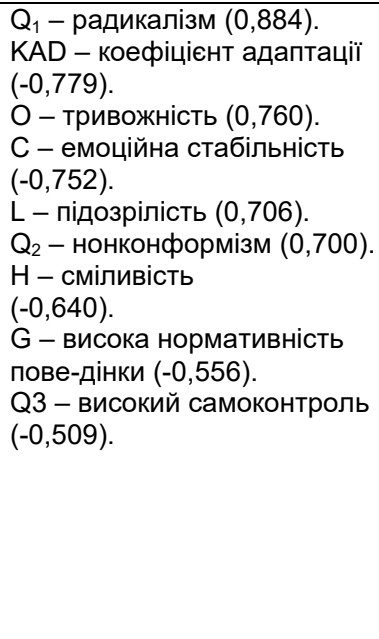 & $\begin{array}{l}\text { (К-Ф) Фемінність } \\
(0,686) \\
\text { (D-M) Dur }(-0,675)\end{array}$ & $\begin{array}{l}\text { Оцінка рівня відчуття себе } \\
\text { дорослим }(-0,859) \text {. } \\
\text { Якість відносин із матір'ю } \\
\text { до призову }(-0,849) \text {. } \\
\text { Оцінка рівня особистої } \\
\text { мужності }(-0,810) \text {. } \\
\text { Якість відносин зі стар- } \\
\text { шими до присяги }(-0,656) \text {. } \\
\text { Якість відносин у родині до } \\
\text { призову (-0,638). } \\
\text { Якість відносин із товари- } \\
\text { шами (-0,623). } \\
\text { Ступінь особистого бажан- } \\
\text { ня проход-ження служби } \\
\text { (-0,586). } \\
\text { Особиста готов-ність вико- } \\
\text { ристо-вувати зброю } \\
\text { (-0,502). } \\
\text { Оцінка рівня особистої } \\
\text { стресо-стійкості (-0,437). }\end{array}$ \\
\hline
\end{tabular}

${ }^{*}$ Статеворольові характеристики: К-Ф - шкала Кочаряна - Фролової; СБ - опитувальник С. Бем; D-M - показник Dur-Moll (маскулінності-сремінності) за методикою С. Сонді

За сукупністю характерологічних ознак за Шмішеком у даний фактор увійшли такі ознаки, як збудливість $(0,697)$, циклотимність $(0,544)$, педантизм $(0,544)$, тривожність $(0,551)$, які вказують на підвищену імпульсивність, ослаблення контролю над потягами i спонуканнями, схильність до страхів, схильність до зміни гіпертимічних і дистимічних фаз, інертність психічних процесів, нездатність до витіснення травмуючих переживань, що може додатково пояснювати наявність ознак нервово-психологічної нестійкості у цьому факторі.

За сукупністю особистих рис методики Кеттела у цей фактор увійшли такі особистісні риси, як: $Q_{1}$ - радикалізм (0,884); О - тривожність $(0,760) ; \mathrm{C}$ - емоційна стабільність $(-0,752)$; L - підозрілість $(0,706) ; Q_{2}-$ нонконформізм $(0,700)$, що характеризують у цілому емоційно нестабільну особистість, яка має звужений комунікативний потенціал.

За статеворольовими характеристиками у цей фактор увійшли феміннність $(0,686)$ за шкалою Кочаряна Фролової та показник Dur $(-0,675)$. Дані характеристики вказують на вираженість фемінінних якостей на психологічному та біологічному рівнях, що певною мірою може бути зумовлено особливостями виховання в батьківській сім'ї, зокрема близькості до матері.

До цього фактора також увійшли показники суб'єктивної самооцінки: оцінка рівня відчуття себе дорослим ($0,859)$, якість відносин із матір'ю до призову $(-0,849)$, оцінка рівня особистої мужності $(-0,810)$, якість відносин зі старшими до присяги $(-0,656)$; якість відносин у родині до призову $(-0,638)$, якість відносин із товаришами $(-0,623)$, ступінь особистого бажання проходження служби $(-0,586)$, особиста готовність використовувати зброю $(-0,502)$, оцінка рівня особистої стресостійкості $(-0,437)$. Дані характеристики вказують на схильність до заниженої самооцінки та низького рівню якості взаємин зі своїм оточенням.
Підсумовуючи всі показники, що становили цей фактор, можна стверджувати, що він характеризує військовослужбовця як особу, нестійку до впливу умов військової служби, із доволі низькою самооцінкою, відсутністю стійких позитивних комунікативних зв'язків у суспільстві, а також егоїстичну та емоційно нестійку, схильну до імпульсивних, і подекуди агресивних, поведінкових виявів.

Як видно з табл. 3, структуру другого фрактора (внесок до сукупної дисперсії 18,226 \%) становили такі психологічні характеристики, як нервово-психічна нестійкість $(0,366)$ та ризик нервового зриву $(0,364)$, що обумовлені відповідними методиками стосовно особистісних та професійних вимог до армійської служби. Дані характеристики вказують на наявність певних ознак особистої нестійкості та збудженості, однак вони недостатньо виражені й можуть перебувати лише на рівні тенденції та виявлятися лише незначною мірою.

За сукупністю виявлених характерологічних ознак за тестом Л. Шмішека у даний фактор увійшла така риса, як тривожність $(0,529)$, яка вказує на особистісну схильність до страхів та лякливість.

За сукупністю особистих рис методики Р. Кеттела у цей фактор увійшли такі особистісні риси, як Q3 - високий самоконтроль (0,679), О - тривожність $(0,475)$, H - сміливість $(-0,415), \mathrm{G}$ - висока нормативність поведінки $(-0,303)$.

Дані характеристики вказують на наявність у структурі особистості таких комунікативних властивостей, як: сором'язливість і нерішучість, уникнення відповідальності й ризику тощо. На рівні емоційних властивостей: схильність до почуття провини, боязкість, невпевненість і тривожність. На рівні поведінкових властивостей: безпринципність, недбалість, легковажність, ненадійність. 


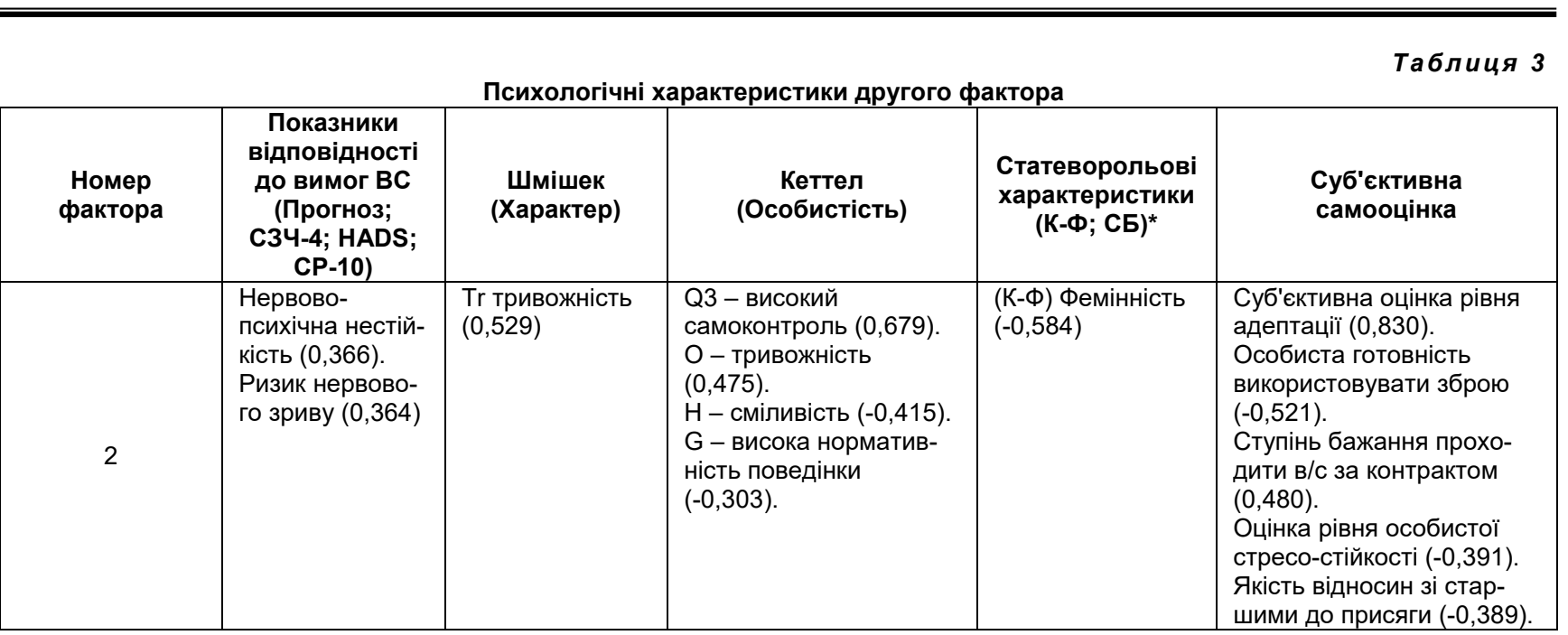

* Статеворольові характеристики: К-Ф - шкала Кочаряна - Фролової; СБ - опитувальник C. Бем; D-M - показник Dur-Моll (маскулінності-фемінінності) за методикою С. Сонді.

Статеворольові показники представлені фремінністю $(-0,584)$ за шкалою Кочаряна - Фролової, що може вказувати на відсутність виражених фемінінних якостей на психологічному рівні та про наявність певного внутрішнього конфлікту особистості, обумовленого, можливо, певною деформацією особистості.

За анкетою суб'єктивної самооцінки факторну вагу набрали такі характеристики: суб'єктивна оцінка рівня адаптації $(0,830)$, особиста готовність використовувати зброю $(-0,521)$, ступінь бажання проходити службу за контрактом $(0,480)$, оцінка рівня особистої стресостійкості $(-0,391)$, якість відносин зі старшими до присяги (0,389). Дані характеристики одночасно вказують на за- вищену оцінку особистих адаптаційних властивостей і на низьку стресостійкість, що може не відповідати реальній ситуації та вимогам до неї з боку соціального середовища.

Підсумовуючи всі показники, що становили цей фактор, можна стверджувати, що він характеризує військовослужбовця як особу, якій властиві внутрішні протиріччя між тривожністю та наявним поведінковим контролем, певним "табу" на вияв фемінінних якостей і неадекватної ненормативної поведінки.

У табл. 4 подано розподіл характеристик, що ввійшли до третього фактора.

Таблиця 4

\begin{tabular}{|c|c|c|c|c|c|}
\hline \multicolumn{6}{|c|}{ Психологічні характеристики третього фактора в/с, схильних до зловживання алкоголю } \\
\hline $\begin{array}{c}\text { Номер } \\
\text { фактора }\end{array}$ & $\begin{array}{c}\text { Показники } \\
\text { відповідності } \\
\text { до вимог ВС* } \\
\text { (Прогноз; С3Ч-4; } \\
\text { HADS; CP-10) }\end{array}$ & $\begin{array}{c}\text { Шмішек } \\
\text { (Характер) }\end{array}$ & $\begin{array}{c}\text { Кеттел } \\
\text { (Особистість) }\end{array}$ & $\begin{array}{c}\text { Статеворо- } \\
\text { льові характе- } \\
\text { ристики } \\
(\text { К-Ф; СБ)* }\end{array}$ & $\begin{array}{l}\text { Суб'єктивна } \\
\text { самооцінка }\end{array}$ \\
\hline 3 & $\begin{array}{l}\text { Ризик нервового } \\
\text { зриву }(0,612) . \\
\text { Тривожність (HADS) } \\
(-0,385) \text {. } \\
\text { Рівень суїцидального } \\
\text { ризику }(0,341) \text {. } \\
\text { Нервово-психічна } \\
\text { нестійкість }(0,308) \text {. }\end{array}$ & $\begin{array}{l}\text { Gi - гіпертимність } \\
(0,872) \text {. } \\
\text { Vo- - } б \text { блливість } \\
(0,518) \text {. } \\
\text { Сi- циклотимність } \\
(0,396)\end{array}$ & $\begin{array}{l}\text { M - мрійливість } \\
(0,882) . \\
\text { F- експресив- } \\
\text { ність }(0,800) \text {. } \\
Q_{2}-\text { нонконфо- } \\
\text { рмізм }(-0,355) .\end{array}$ & - & $\begin{array}{l}\text { Оцінка рівня особистої мужності } \\
\text { (0,448). } \\
\text { Ступінь бажання проходити в/с } \\
\text { за контрактом }(0,397) \text {. } \\
\text { Ступінь особистого бажання } \\
\text { проходження служби }(0,395) \text {. } \\
\text { Якість відносин у родині } \\
\text { до призову }(0,382) \text {. } \\
\text { Якість відносин із матір'ю } \\
\text { до призову }(0,372) \text {. } \\
\text { Оцінка рівня відчуття себе } \\
\text { дорослим }(0,327) \text {. } \\
\text { Особиста готовність використо- } \\
\text { вувати зброю }(0,320) \text {. }\end{array}$ \\
\hline
\end{tabular}

* Статеворольові характеристики: К-Ф - шкала Кочаряна - Фролової; СБ - опитувальник C. Бем; D-M - показник Dur-Moll (маскулінності-фремінності) за методикою С. Сонді.

Як видно з табл. 4, структуру третього фрактора (внесок до сукупної дисперсії 16,619 \%) становили наступні характеристики.

Так, згідно з особистісними та професійними вимогами, до армійської служби обумовлених відповідними методиками, до цього фактора увійшли такі особистісні показники: ризик нервового зриву $(0,612)$, тривожність HADS $(-0,385)$, рівень суїцидального ризику $(0,341)$, нервово-психічна нестійкість $(0,308)$. Дані характеристики, так, як і у перших двох фракторах, указують на знижену загальну психологічну стійкість.

За сукупністю виявлених характерологічних ознак за тестом Шмішека у даний фактор увійшли такі: Gi - гіпе- ртимність $(0,872)$, Уo - збудливість $(0,518), \mathrm{Ci}$ - циклотимність $(0,396)$, які вказують на підвищений фон настрою в поєднанні з оптимізмом і високою активністю одночасно зі схильністю до вияву імпульсивних поведінкових виявів. Циклотимність у даному випадку може вказувати на певну схильність до змін настрою, проте не виражену та короткочасну.

За сукупністю особистих рис методики Кеттела, у цей фактор увійшли такі особистісні риси, як М - мрійливість $(0,882), F-$ експресивність $(0,800)$, Q2 - нонконформізм $(-0,355)$. Дані характеристики вказують на наявність у структурі особистості таких комунікативних властивостей: залежність від групи та чужої думки; інтелектуальних 
властивостей: мрійливість, поглиблення в себе та безпорадність у практичних справах, можливі істеричні вияви та конфліктність у колективі. На емоційному рівні - безтурботність, імпульсивність і балакучість.

До даного фактора статистично значущих статеворольових показників не ввійшло, що може дозволити нам характеризувати даний фрактор як гендерно невизначений.

За анкетою суб'єктивної самооцінки фракторну вагу набрали такі характеристики: оцінка рівня особистої мужності $(0,448)$, ступінь бажання проходити в/с за контрактом $(0,397)$, ступінь особистого бажання проходження служби $(0,395)$, якість відносин у родині до призову $(0,382)$, якість відносин із матір'ю до призову $(0,372)$, оцінка рівня відчуття себе дорослим $(0,327)$, особиста готовність використовувати зброю $(0,320)$. Ці характеристики вказують на наявність позитивної військово-професійної спрямованості, позитивну особистісну самооцінку та схильність до побудови якісних відносин у родині, але їхня факторна вага не перевищує 0,500 , що вказує на їх вияв лише на рівні тенденцій.

Підсумовуючи всі показники, що становили цей фрактор, можна стверджувати, що він характеризує військовослужбовця як особу, якій властиві підвищений фон настрою в поєднанні зі схильністю до імпульсивних поведінкових виявів або емоційного зриву.

Загалом фракторна структура описує військовослужбовця, схильного до вживання алкоголю, як доволі психологічно та емоційно нестійку особистість. Їй властиві наявність внутрішньо-особистісного конфрлікту, який може бути наслідком виховання в батьківській родині в період формування гендерної ідентичності, що у подальшому може впливати на особливості побудови комунікації та емоційних зв'язків не тільки із своїми батьками, а й оточуючими.

Висновки 3 дослідження та перспективи подальшого розвитку

1. У результаті дослідження виявлено, що військовослужбовці схильні до зловживання алкоголю, мають специфічну факторну структуру. По-перше, у гендерному контексті вона містить внутрішньо-особистісний конфллікт (між схильністю щодо вияву фемінних якостей та одночасно накладання на їх вияв певного "табу"). Унаслідок цього, можуть з'являтися нестійкі поведінкові реакції та підвищення рівня тривожності. По-друге, відсутність у виявленій факторній структурі алкозалежної особистості показників маскулінності та андрогінності може вказувати на звужений спектр вияву нею демонстрації необхідних якостей чоловічої поведінки, певну соціальну незрілість, обумовлену соціальною роллю, а саме - перебуванням у військовому колективі, що у подальшому підвищує рівень стресового навантаження на неї.

2. У факторній особистісній структурі військовослужбовців, схильних до алкоголізації, виявлено такі основні стрижневі особистісні показники, як нервовопсихічна стійкість, ризик до нервового зриву та особиста готовність до використання зброї з інверсивною динамікою. Характерологічними рисами психологічного портретує збудливість, циклотимність, тривожність, нонконформізм і ненормативна поведінка.
3. Чутливими до визначення критеріальних вимог щодо виявлення військовослужбовців, схильних до алкозалежності, є методики "Прогноз" і тест Шмішека.

4. Фокусом психокорекційного впливу психолога частини на особистість алкозалежних військовослужбовців має стати проведення тренінгових занять, направлених на формування позитивного образу військовослужбовця та андрогінної моделі поведінки за рахунок побудови адекватних відносин із начальниками та командирами-чоловіками, а також із референтною гомогенною групою співслужбовців, яка $€$ дуже важливим колом соціального впливу. Створення груп підтримки на рівнях психолог - військовослужбовець та військовослужбовець - військовослужбовець, які в перспективі будуть компенсувати можливі вияви імпульсивних та соціально-незрілих виявів ненормативної поведінки.

\section{Список використаних джерел}

1. Цензор.нет [Електронний ресурс]. https://censor.net.ua/n460850.

2. Балашова С. П. Практичний курс військової психології : навч. посіб. ; у 2-х ч. / С. П. Балашова, С. П. Васильєв, Г. Р. Дубровинський. К. : ВПЦ "Київський університет", 2013. - Ч. 2. - 172 с.

3. Савин А.Д. Сущность отклоняющегося поведения военнослужащих / А. Д. Савин // Теория и практика общественного развития. Педагогические науки. № 9. - Краснодар. - 2012. - С. 124-127.

4. Сукачева О.Н. Результаты исследования мотивов употребления алкоголя у кадрових военнослужащих с признаками расстройства адаптации, уволенных из рядов Вооруженных Сил в процессе реформирования армии / О.Н.Сукачева // Укр. вісн. психоневрології. Діагностика та лікування психічних та наркологічних розладів. - Т. 23. - Вип. 1(82). 2015. - C. $104-108$

5. Бахтин И. С. Личностные особенности курсантов военно-морских высших военных учебных заведений, склонных к аддиктивному поведению / И. С. Бахтин : дис. ... канд. психол. наук. - СПб. ГУ / факультет психологии. - 2016. - 197 с.

6. Психическое развитие воспитанников детского дома/под ред. И. В. Дубровиной, А. Г. Рузской. - М. : Педагогика, 1990. - 264 с.

7. Сергиенко Е. А. Проблемы психичекого развития: некоторые острые вопросы и пути их решения / Е. А. Сергиенко // Психолог. журн. 1990. - T. 2. - С. 150-160.

8. Гошовський Я.О. Становлення образуЯ в підлітків школиінтернату в умовах депривації батьківського впливу : автореф. дис. канд. психол. наук: спец. 19.00.07 "Педагогічна та вікова психологія" / Я. О. Гошовський. - К., 1995. - 24 с.

\section{Reference}

1. Tsenzor net [Elektronnyi resurs] - https://censor.net.ua/n460850

2. Balashova S. P. Praktychnyi kurs viiskovoi psykholohii : Navch. pos. Ch. 2 / S. P. Balashova, S. P. Vasyliev, H. R. Dubrovynskyi. - K. : Kyivskyi natsionalnyi universytet imeni Tarasa Shevchenka, 2013. - $172 \mathrm{~s}$.

3. Savin A. D. Sushchnost otkloniaiushchegosia povedeniia voennosluzhashchikh / A. D. Savin // Teoriia i praktika obshchestvennogo razvitiia. Pedagogicheskie nauki № 9. - Krasnodar. - 2012. - S. 124-127.

4. Sukacheva O. N. Rezultaty issledovaniia motivov upotrebleniia alkogolia u kadrovykh voennosluzhashchikh s priznakami rasstroistva adaptatsii, uvolennykh iz riadov Vooruzhennykh Sil $v$ protsesse reformirovaniia armii / O.N. Sukacheva // Ukrainskyi visnyk psykhonevrolohii. Diahnostyka ta likuvannia psykhichnykh ta narkolohichnykh rozladiv. - T. 23, vyp. 1(82). - K., 2015. - S. 104-108.

5. Bakhtin I. S. Lichnostnye osobennosti kursantov voenno-morskikh vysshikh voennykh uchebnykh zavedenii, sklonnykh $\mathrm{k}$ addiktivnomu povedeniiu / I. S. Bakhtin : Diss. ... kand. psikhol. nauk. - SPb GU, fakultet psikhologii. - 2016. - $197 \mathrm{~s}$.

6. Psikhicheskoe razvitie vospitannikov detskogo doma/ Pod red. I. V. Dubrovinoi, A. G. Ruzskoi. - M. : Pedagogika, 1990. - 264 s.

7. Sergienko E. A. Problemy psikhichekogo razvitiia: nekotorye ostrye voprosy i puti ikh resheniia / E. A. Sergienko // Psikhologicheskii zhurnal. 1990. - T. 2. - S. 150-160.

8. Hoshovskyi Ya. O. Stanovlennia obrazu Ya v pidlitkiv shkoly-internatu v umovakh depryvatsii batkivskoho vplyvu: Avtoref. dys. ... kand. psykhol. nauk: spets. 19.00.07 "Pedahohichna ta vikova psykholohiia" / Ya. O. Hoshovskyi. - K., 1995. - 24 s

Надійшла до редколегії 15.10.18

В. Мозговой, канд. психол. наук, докторант

Киевский национальный университет имени Тараса Шевченко, Киев

\section{ИССЛЕДОВАНИЕ СТРУКТУРНОЙ ОРГАНИЗАЦИИ ЛИЧНОСТИ ВОЕННОСЛУЖАЩИХ,} СКЛОННЫХ К ЗЛОУПОТРЕБЛЕНИЮ АЛКОГОЛЯ В КОНТЕКСТЕ ИХ ПОЛОРОЛЕВОГО СТАТУСА

Исследованы особенности структурной организации личности военнослужащих, склонных к злоупотреблению алкоголя. Определен дальнейший фокус работы психолога воинской части с данной категорией лиц в зависимости от выявленного полоролевого статуса военнослужащих, склонных к злоупотреблению алкоголя.

Ключевые слова: факторная структура личности, полоролевой статус, военнослужащий. 
V. Mozgovyi, Ph. D.

Taras Shevchenko National University of Kyiv, Kyiv

\section{RESEARCH OF STRUCTURAL ORGANIZATION OF THE PERSONALITY OF MILITARY SERVICE CIRCULAR TO ALCOHOLEXTREMELY IN THE CONTEXT OF THEIR GENDER-ROLE STATUS}

The article deals with the features of the structural organization of the personality of the servicemen who are prone to alcohol abuse. Determined the further focus of the psychologist's part with this category of persons, depending on the identified sex-role status of servicemen who are prone to alcohol abuse. According to the purpose the following tasks have been set: To investigate the specifics of the factor structure of servicemen who are prone to alcohol abuse; Identify the main pivotal features of their psychological portrait; To outline the main ways of psycho-corrective work with the personnel, who are prone to alcohol abuse depending on sexual role status. In total, 64 servicemen of the State Special Transport Service (MoDST) of the Ministry of Defense of Ukraine participated in the study. Research methods are: Prognosis, SZCh-4, HADS, CP-10, Kettel's personal questionnaire, Shmishek's test, self-esteem questionnaire, S. Bem method (determination of level of masculinity / femininity assessment) and structural gender-role scale (A. Kocharyan - EV Frolova), as well as Dur-Moll (masculinity-femininity, respectively) by S. Sondi's method. The study revealed the character traits of a psychological portrait of servicemen who are prone to alcohol abuse: excitability, cyclothymia, anxiety, non-conformism and abusive behavior. The following key core personality indicators have been identified such as neuropsychiatric resistance, risk of nerve failure, and personal readiness to use inverted dynamics weapons. The focus of psycho-corrective influence of part of the psychologist on the personality of alcohol addicted servicemen should be to conduct training sessions aimed at forming a positive image of the serviceman.

Keywords: factor structure of the person, sex-role status, serviceman.

Bulletin of Taras Shevchenko National University of Kyiv. Series "Psychology". № 2(9), pp. 47-51 (2018)

УДК 159.97

DOI: https://doi.org/10.17721/BSP.2018.2(9).12
ISSN 1728-3817

(C) Taras Shevchenko National University of Kyiv, Publishing Center "Kyiv University", 2018

В. Морозова, студ.

\section{ПСИХОЛОГІЧНІ ОСОБЛИВОСТІ ОСІБ ІЗ МЕЖОВИМ РОЗЛАДОМ ОСОБИСТОСТІ}

Подано результати емпіричного дослідження психологічних особливостей осіб із ознаками межового розладу особистості. Доведено, що емоційна лабільність (нестійкість емоцій), імпульсивність та самоушкоджувальна поведінка є важливими діагностичними критеріями межового розладу особистості. Високий рівень вияву ознак межового розладу особистості супроводжується такими психічними станами дезадаптації, як невротична депресія, астенія, напруженість і тривожність.

Ключові слова: межовий розлад особистості, невротичні стани, нестійкість емоцій, самоушкоджувальна поведінка, імпульсивність, тривожність.

Постановка проблеми. Сучасний стан ситуації психічного здоров'я в нашій країні відображається у звіті Міністерства соціальної політики України за 2017 р., де йдеться про те, що Україна посіла перше місце в Європі за кількістю психічних розладів. За офріційною статистикою, в Україні 1,2 млн мешканців (більше $3 \%$ ) страждає психічними розладами і щорічно майже 2 млн осіб стають пацієнтами психіатричних лікарень [8]. Зазначимо, що межовий розлад особистості $\epsilon$ серйозною і багатоаспектною, але все ще маловивченою проблемою. У Міжнародній класифікації хвороб MKX-10 відсутнє чітке визначення межового розладу особистості; воно розглядається як різновид емоційного нестійкого розладу (F60.3). У більш вузькоспеціалізованому класифікаторі психічних розладів DSM-5 даний розлад позначено окремим пунктом (301.83). Особлива увага дослідників даної проблеми приділяється питанням діагностики, причинам виникнення і розвитку межового розладу особистості. Поняття "межовий розлад особистості" $\epsilon$ відносно новим у психопатології. Воно не входило в діагностичні посібники із психічних розладів Американської психіатричної асоціації до 1980 р. (у цьому році з'явилося перероблене і доповнене видання Diagnostic and Statistical Manual of Mental Disorders DSM-III). Особливо гострим моментом проблеми є той фракт, що для осіб із МРО характерні суїцидальні думки та спроби, а також парасуїцидальна поведінка, самоушкодження тощо. Одним із найбільших страхів людей із MPO є страх розриву значущих і близьких відносин. Особи з МРО дуже бояться самотності, але при цьому в них відсутне розуміння того, що їх прагнення утримати партнера відлякує його. На самоті у них можуть спостерігатися виражені стани деперсоналізації та дереалізації й перемикання між цими станами. Різкі стрибки у відносинах призводять до афектів (тривоги, сорому, самозвинувачення і самоприниження, залучення до саморуйнівної поведінки тощо). Розрив відносин із значущою особою $\epsilon$ величезним стресом для людини 3 межовим розладом особистості. Якщо людина 3 МРО відчуває себе покинутою, вона може впадати в паніку, депресію, або навпаки, гнів, може також піти на відчайдушні вчинки. Реакції людини в ситуації стресу дозволяють визначити наявність МРО. У ситуації стресу в людей із межовим розладом особистості можуть спостерігатися дестабілізація в когнітивній, поведінковій та емоційній сфрерах, а також дезадаптація.

Аналіз досліджуваності проблеми. Останні роки значно підвищився інтерес до проблеми межового розладу особистості (MPO) як серед психологів, так і серед представників суміжних наукових галузей (медицині, психіатрії). Це обумовлено тим фактом, що у пацієнтів 3 різними формами розладів особистості, симптоми МРО спостерігаються приблизно в $33 \%$ амбулаторних, та у $63 \%$ хворих, що проходять лікування у стаціонарних відділеннях [3, с. 6-7].

А. Штерн (1939) описав хворих, які проходять амбулаторне лікування і яким не допомагав класичний психоаналіз, а також таких, які не вписувалися в категорії "невротичних" або "психотичних" пацієнтів. С. Радо (1956) позначав межовий розлад особистості як "екстрактивний розлад". С. Лессер і Б. Ессер (1965) позначали МРО як "істероідний розлад". Загальні ознаки, властиві особам із МРО, виділяли Р. Грінкер, Р. Драй і Б. Вербль (1968).

Серед сучасних дослідників проблеми межового розладу особистості особливої уваги заслуговує досвід американського психолога, засновниці діалектикоповедінкової терапії М. Лайнен. Вона виділяє низку поведінкових паттернів при межовому розладі особистості та упроваджує доволі ефективні методи подолання межового розладу особистості [3].

Зазначимо, що межовий розлад особистості - це розлад психіки, за якого зазначається емоційна нестабільність поведінки. Особи з межовим розладом особистості мають ряд психологічних особливостей, які ускладнюють процес їх соціальної адаптації. Різкі перепади настрою, афективна нестійкість, імпульсивність, дратівливість - усе це несприятливо позначається на взаєминах з іншими людьми. Оточення схильне приписувати такій людині "важкий характер" і цуратися його, або ж вороже до нього 